\title{
A PRAGMATIC STUDY OF REQUEST HEAD ACTS AND EXTERNAL MODIFICATIONS AS SEEN IN FROZEN
}

\section{Reri Rahmat Riyadi Putra}

\section{INTISARI}

Skripsi ini meneliti tentang ungkapan permintaan dalam Frozen, sebuah film animasi 3-dimensi Amerika yang beraliran musikal, fantasi, dan komedi. Data penelitian ini merupakan 76 ungkapan permintaan yang dikumpulkan dari film tersebut, disertai dengan konteksnya. Secara khusus, penelitian ini bertujuan untuk mengklasifikasi dan menganalisis permintaan berdasarkan pada aksi pokok dan modifikasi eksternal dari ungkapan permintaan, serta untuk menemukan tipe dominan yang muncul dalam film tersebut. Aksi pokok akan dikelompokkan berdasarkan teori strategi ungkapan permintaan dari BlumKulka dan Olshtain (1984): direct, conventionally indirect, dan indirect request. Modifikasi eksternal akan dikelompokkan berdasarkan teori strategi modifikasi eksternal dari BlumKulka, House, dan Kasper (seperti yang terkutip dalam Schauer, 92): preparator, grounder, disarmer, imposition minimizer, sweetener, dan promise of reward. Berdasarkan klasifikasinya, dapat dilihat bahwa strategi direct request adalah strategi yang paling diminati dalam menyampaikan permintaan dengan 50 (65.79\%) kejadian dan grounder adalah strategi yang paling diminati dalam memodifikasi permintaan dengan 23 (67.65\%) kejadian. Tingginya frekuensi direct strategy bisa disebabkan oleh keakraban karakter di dalam jalan ceritanya dan grounder bisa disebabkan oleh begitu mudahnya menggunakan grounder dalam memodifikasi permintaan.

Kata kunci: tindak tutur, permintaan, aksi pokok, modifikasi eksternal, konteks 


\begin{abstract}
This research attempts to investigate the requests in Frozen, an American 3D computer-animated musical fantasy-comedy film. The data comprise 76 requests collected from the subtitles of the movie, along with the context. Specifically, it aims to classify and analyze the requests' head acts and external modifications, and to find out the more dominant strategy appears in the movie. The classification of the head act was according to the theory of request strategies proposed by Blum-Kulka and Olshtain (1984): direct, conventionally indirect, and non-conventionally indirect. The classification of the external modification was according to the theory of external modification strategies proposed by Blum-Kulka, House and Kasper's classification (qtd. in Schauer, 92): preparator, grounder, disarmer, imposition minimizer, sweetener, and promise of reward. Based on the classification, it can be seen that direct strategies is the most preferred strategies in uttering requests with 50 (65.79\%) occurrences and grounder is the most preferred strategies in modifying requests with 23 (67.65\%) occurrences. The high frequency of direct strategy might be caused by the characters' intimacy in the storyline and grounder might be caused by the easiness of using grounder in modifying requests.
\end{abstract}

Keywords: speech act, requests, head act, external modification, context

\section{INTRODUCTION}

Request is an utterance to express desires to ask others about or to do something. Searle (qtd. in Félix-Brasdefer, 2007) defines a request as an act whose purpose is to get the hearer to do something which is not obvious that the hearer will perform the action. By initiating a request, the speaker believes that the hearer is able to perform an action.

Request consists of two main parts, the head act and the modification (FélixBrasdefer, 2007). The head act, the core request, consists of the main utterance which has the function of requesting and can stand by itself. The head act may have various forms based on the strategy types and levels of directness. Blum-Kulka and Olshtain (1984), in Cross Cultural Study of Speech Act Realization Patterns (CCSARP), propose a scale to classify request based on the levels of directness which is basically composed by three strategies; direct, conventionally indirect, and non-conventional indirect. While the head act is classified into three types, the modification, the optional item that serves to either mitigate or intensify the force of the requesting move, is classified into two types, internal modification which appears within the request act, and external modification which appears in the immediate linguistic context rather than in the request act itself. Considering the fact that request may threaten the hearer's negative face, the use of these modifications is essential so that the speakers' requesting utterances may be considered as appropriate in a variety of situations. In this research, the writer actually focuses on how indirectness associate with politeness in the speech act of requests, including the head acts and the modifications.

As the object of the research, the writer takes Frozen, an American 3D computer-animated musical fantasy comedy-drama film ${ }^{1}$ produced and released by Walt Disney in November, 2013. The film tells the story of a princess, Anna, who sets off on an epic journey with a thrill-seeking mountain man, Kristoff, with his loyal pet reindeer, Sven, and a helpless snowman, Olaf, to find her alienated sister, Elsa, the Queen of

\footnotetext{
${ }^{1}$ The Disney Wiki, accessed on 12 Mar. 2014
} 
Arandelle, whose icy powers have accidentally trapped her kingdom in eternal winter and Hans, a prince who tries to take over Arandelle. The main goal of this research is to study speech act of request based on the request head act and external modification strategies uttered by the characters in the movie, and the objectives of the research are to identify and classify the request head act and external modification found in the movie to see the more dominant strategy of each of them which appears in the movies.

The discussion of this paper is limited to the analysis of requests, and will not be done on the other speech acts. The data are all requests and their contexts found in an American 3D computeranimated musical fantasy comedy-drama film entitled Frozen. Although the data are in the form of conversations, there will not be any phonological analysis. Furthermore, the analysis will only focus on the strategies of request head act and external modification.

\section{METHOD}

The data collection was done by watching the movie and observing the subtitle closely. The data, the subtitles from the movie containing request expressions uttered by the characters in the movie, were transcribed. In order to give a clearer description of the situations of the dialogues, the data were transcribed along with their contexts.

In analyzing the data, there were some procedures required. First of all, the data of the head acts, the actual requests were sorted based on the request strategies depending on the levels of directness proposed by Blum-Kulka and Olshtain (1984); direct, conventionally indirect, and non-conventional indirect. Based on the classification, the data were calculated and presented in a table. Following the table, the explanation of the classification of request strategies was presented. Later, the sorted data were identified whether they uttered with external modification or not. The data uttered with external modification were classified based on the external modification strategies proposed by Blum-Kulka, House and Kasper (qtd. in Schauer, 92); preparator, grounder, disarmer, imposition minimizer, sweetener, and promise of reward. The data uttered without external modification were not analyzed. The frequencies of the classified data based on the external modification strategies were calculated and presented in a table. The explanation of the classification of external modification strategies was presented afterwards.

\section{PREVIOUS RESEARCHES}

In a research under the title of "Indirectness and Politeness in Mexican Requests", Félix-Brasdefer (2005) investigated the notions of indirectness and politeness in the speech act of requests, including head acts and external modifications, among Mexican university students in formal and informal role-play situations. In examining the head act and external modification, he applied the theory proposed by Blum-Kulka and Olshtain (1984). It was found that conventionally indirect was the preferred strategy in uttering requests and reasons (grounder) was the preferred strategy in modifying requests. In conclusion, he stated that conventionally indirect requests increased levels of deferential politeness and were used to express respect or distance between the interlocutors.

Another research has been done by Putro (2009). In his research entitled 'Indonesian Students' Request in English: Forms, Perspective, and Modifier", he analyzed the English requests made by students of the English Department of Universitas Gadjah Mada in which the age and social factor affect the situations. Applying theory proposed by Sifianou (1992) in analyzing the requests and the modifiers, he found that grounder is the 
modifier which is mostly used by the students to modify their requests. He also found that in uttering English requests, the students seem to be affected by their native culture, particularly in their use of grounder.

In addition, a research investigating request modifications was also conducted by Saeko Fukushima (2011). Under the title of "External mitigation: Supportive move in Japanese requests", she investigated supportive moves in Japanese requests, exploring the frequency and the kinds of supportive moves in relation to power difference and distance between the speaker and the hearer, degree of imposition of the requested act, and (in)directness of the head acts. In her research, she focused on investigating the external modification based on the theory proposed by Blum-Kulka and Olshtain (1984). Lastly, she concluded that grounders were most frequently used among all of the supportive moves. She also suggested that supportive moves can be used in order to receive compliance of the request from the hearer.

This present research is quite similar to those researches described above since it focuses on the request head act and external modification. In this research, the utterances that have been identified as requests will then be classified based on request and external modification strategies. This present study, however, did not use Discourse Completion Task (DCT) as is used in those previous researches to collect the data. Since the data of this research are taken from the subtitles of a movie and the theories applied to this research is quite different, the result of this research might be different from those of the previous researches.

\section{FINDINGS AND DISCUSSION}

This section is divided into two parts. The first presents the findings of the head acts according to the classification proposed by Blum-Kulka and Olshtain (1984) and the second presents the findings of the external modifications according to the classification by BlumKulka, House and Kasper (qtd. in Schauer, 92). The analyses in this chapter will be discussed by presenting some examples from the data. Later in the examples, the head acts and the external modifications being analyzed will be typed in bold and underlined.

\section{Request Head Acts}

Based on the data source, there are 76 requests found. Table 1 below shows the distribution of request strategies found in the data.

\begin{tabular}{|c|l|c|c|}
\hline No. & \multicolumn{1}{|c|}{ Request strategies } & NO & $\%$ \\
\hline 1. & Direct & 50 & 65.79 \\
\hline 2. & $\begin{array}{l}\text { Conventionally } \\
\text { indirect }\end{array}$ & 7 & 9.21 \\
\hline 3. & $\begin{array}{l}\text { Non-conventional } \\
\text { indirect }\end{array}$ & 19 & 25 \\
\hline & \multicolumn{1}{|c|}{ Total } & 76 & 100 \\
\hline
\end{tabular}

Table 1. Number of request strategies

Notes: $\mathrm{NO}=$ Number of Occurrences, $\%=$ Percentage

Furthermore, the table also shows that the most frequent request strategy appears is direct strategy with $50 \quad(65.79 \%)$ occurrences, followed by nonconventional indirect strategy with 19 $(25 \%)$ occurrences, and conventionally indirect strategy with $7 \quad(9.21 \%)$ occurrences. The analysis of the classified request strategies are presented in the subsections as follows.

\section{Direct strategies}

According to Blum-Kulka and Olshtain (1984), requests formed in imperatives, performatives, and hedged performatives belong to direct strategies. Some examples of the occurrences of direct requests are as follows. 
[12] Elsa : "Please, just stay away from me."

[13] Anna : "Please tell me I'm almost there."

As seen in the examples above, both of them are requests formed in imperatives. In addition, direct requests are often internally modified by the lexical mitigator 'just' and 'please' to soften the harshness of direct requests. No occurrence of direct strategies formed in performatives and hedged performatives are found. However, direct strategies are possibly also found in these sentences:

[14] Anna : "I need you here to take care of Arandelle."

[15] Anna : "I want you to take me up the North Mountain."

The words 'I need' and 'I want' explicitly represent the speakers' desires to get the hearers doing something. Those words and others certain similar words might be the signals of direct requests since they help explicitizing the speakers' desires. Furthermore, occurrences of direct strategies can also be found in the request utterances in which the requested act asked to the hearer is obligated by the speaker. The examples are as follows.

[16] Elsa : “... Wait, it does not matter. Just... You have to go."

[17] Elsa : “... You have to tell them to let me go."

Lastly, request utterances mentioning the ability, or permission and prohibition, marked by word 'can' as the modal of ability, given to the hearers for doing the act desired by the speakers also belong to direct strategies. The examples are as follows.

[18] Anna : "Whatever you have to say, you can say to both of us."

[19] Hans : "Elsa! You can't run

from this."
Based on the examples presented above, direct strategies are found in the requests in which the speakers' desires are consistent with the propositional content of the utterance, and are conveyed unambiguously. Thus, direct request strategies convey only one meaning or illocutionary force. Pronoun ' $y o u$ ' in the utterances is also the indicator that those strategies are direct since it directly address the hearers as the performers of the requested act.

\section{Conventionally indirect strategies}

According to Blum-Kulka and Olshtain (1984), the use of words 'would' and 'could' is the typical of conventionally indirect strategy.

\section{[20] Hans $\quad$ : “... Will you marry me?" \\ [21] Kristoff talking about this?" \\ : “Can we just stop}

The words 'will' and 'can' in those examples is also to seek the hearers' willingness or ability to perform the requested act. Compared with the previous strategy, conventionally indirect strategies give more possibility to the hearers to say no to the requests since this strategy forms requests in interrogative sentence, as examples [20] and [21] formed in yes-orno questions. Conventionally indirect strategies can also be done by seeking the hearer's permission, as follows.

[22] Elsa : "May I talk to you, please? Alone."

Still in the form of interrogative sentence, the example below is also an example of a request belongs to conventionally indirect strategies.

[23] Anna : "Oh, great. For now, um, how about boots?

Winter boots and dresses?" 
Example [23] conveys Anna's desire to get Oaken, the trader, \& the offer winter equipments to her through utterance phrased as a suggestion formed in interrogative sentence. Although there is no word 'offer' in the utterance signaling her desire, the request is not ambiguous because contextually, the trader has offered summer equipments previously. Since Anna needs winter equipments not summer equipments, she asks winter equipments to be offered.

Besides interrogative sentence, the request formed in certain declarative sentence can also be possible to be recognized as a request which belongs to conventionally indirect strategies:

[24] Anna \& Hans : "We would like... Uh, your blessing...

\section{Of our marriage."}

[25] Anna : "Do you like it?"

Kristoff : "Like it? I love it!I could kiss you. I could. I mean, I'd like to. I'd... May I? We me. I mean, may we? Wait, what?"

Sofyan and Rusmi (2011: 70) state that in English, the declarative such as ' $I$ ' $d$ like' is a conventionalized way of stating a request, in which the modal 'would' enhances the unreal and hypothetical. Both of the examples are utterance in declarative sentence, through which the requested acts are conveyed explicitly but in the level which is less direct than direct strategies because the speakers do not directly address the hearers to perform the requested act.

Although the speakers utter their desires consistently with the propositional content of the utterances and unambiguously just like direct strategies, in conventionally indirect strategies, they also soften the illocutionary force of their requests by giving the hearers position of power to grant permission to perform the requested act by uttering interrogative sentence, or by uttering declarative sentence such as 'I'd like' which explicitly declares what the speakers want but indirectly address the hearers to perform the requested acts. Thus, since this strategy is in the middle level of directness, the threatening acts level of conventionally indirect strategies is lower than direct strategies but higher than nonconventionally indirect strategies.

\section{Non-conventional indirect strategies}

According to Blum-Kulka and Olshtain (1984), non-conventional indirect strategies are hints, divided into two types: hints mentioning partial reference to object or element needed for the implementation of the act called strong hints because they directly pragmatically imply the act, and hints mentioning reliance on contextual clues called mild hints because they indirectly pragmatically imply the act. Based on the occurrences of nonconventional indirect strategies, both of the hints are found in the data. Below are the examples of the hints.

\begin{tabular}{|c|c|}
\hline $\begin{array}{l}{[26] \text { Bishop }} \\
\text { the gloves." }\end{array}$ & "Your Majesty, \\
\hline $\begin{array}{l}{[27] \text { Kristoff }} \\
\text { you." }\end{array}$ & "Carrots. Behind \\
\hline $\begin{array}{c}\text { Anna } \\
\text { Excuse me." }\end{array}$ & “Oh! \\
\hline $\begin{array}{l}\text { [28] Kristoff } \\
\text { ice." }\end{array}$ & "She's cold as \\
\hline $\begin{array}{l}{[29] \text { Anna }} \\
\text { gates." }\end{array}$ & "I like the open \\
\hline $\begin{array}{l}\text { Elsa } \\
\text { ssing them again." }\end{array}$ & "We are never \\
\hline
\end{tabular}

As seen in the previous examples, all the speakers do not mention what acts they desire to be performed and who will be the performers explicitly but only mention the hints related to their requests. The strong hints mention some parts of the request, as uttered in example [26], 'the gloves' which is the hint that the Bishop wants Elsa to put her gloves off, and in example [29], 'the open gates' which is the hint that Anna wants Elsa to keep the gates opened, or not to close the gates. 
Compared with strong hints, mild hints are harder to be recognized as requests since they do not mention any parts of the requests. As uttered in example [27], Kristoff is indirectly asking Anna to give him space to get carrots which is located behind her, and in example [28], he is indirectly asking for help by only declaring Anna's condition, which makes the utterance hard to be recognized as a request and ignored. However, Kristoff's hints in example [27] are recognized by Anna in the end. Although when she hears 'Carrots', she does not recognize it, when she hears 'Behind you', she recognizes that there is an act that wanted by Kristoff to be performed by Anna.

Finally, non-conventional indirect strategies, hints, are defined as utterances in which the speakers' meaning and the propositional content are not identical, which the implicitness gives nonconventional indirect strategies possibility to convey more than one meaning. Compared to direct and conventionally indirect strategies, hints are also more likely to be misinterpreted or not recognized as a request as hints are uttered in declaratives. Sofyan and Rusmi (2011: 70) state that the use of hints is expressing requests in the declaratives.

\section{Request External Modifications}

From 76 requests, there are 31 requests uttered with external modifications, and from those 31 requests, there are 3 requests which is uttered with more than one external modifications. However, the analysis of the combined external modification strategies is not presented separately with the main classification of external modifications.

\begin{tabular}{|c|l|c|c|}
\hline No. & $\begin{array}{c}\text { External modification } \\
\text { strategies }\end{array}$ & NO & $\%$ \\
\hline 1. & Preparator & 2 & 5.88 \\
\hline 2. & Grounder & 23 & 67.65 \\
\hline 3. & Disarmer & 2 & 5.88 \\
\hline 4. & Imposition minimizer & 2 & 5.88 \\
\hline 5. & Sweetener & 4 & 11.76 \\
\hline
\end{tabular}

\begin{tabular}{|c|c|c|c|}
\hline 6. & Promise of reward & 1 & 2.94 \\
\hline & Total & 34 & 100 \\
\hline
\end{tabular}

Table 2. Number of external modification strategies

Notes: $\mathrm{NO}=$ Number of Occurrences, $\%=$ Percentage

This table also shows that grounder with $23(67.65 \%)$ occurrences is the most preferred external modification strategy employed to modify the requests. The following rank is sweetener with 4 $(11.76 \%)$ occurrences, and preparator, disarmer, and imposition minimizer are in the same rank, as all of them have 2 (5.88\%) occurrences. Lastly, promise of reward is the least preferred external modification strategies, with only 1 $(2.94 \%)$ occurrences. The low frequency of the promise of reward might be caused by the effort needed by the speaker to give the hearer reward for fulfilling the request.

\section{Preparator}

Preparator is a strategy of external modification which is intended to prepare the hearer for the requests. Below are the examples.

[30] Hans : "Can I say something crazy? Will you marry me?"

[31] Olaf : "Hey, do me a favor. Grab my butt."

As seen in examples above, both of them have another utterance placed before the request, which is the preparator. Since both requests are fulfilled by the hearers, it can be concluded that the hearers might be more likely to perform the requests if they have been prepared previously.

\section{Grounder}

Grounder can be easily uttered by providing anything, i.e. reasons, explanations, or justifications, along with the requests utterances, as follows.

[32] Anna : "Bring me my horse, please." 
Hans : “Anna, no. It's too dangerous."

[33] Hans : "Bring back summer... Please."

Elsa : "Don't you see? I can't. You have to tell them to let me go."

[34] Anna : "Please, Olaf, you can't stay here. You'll melt."

[35] Anna : "Help me up, Olaf. Please."

Olaf : "No, no, no. You need to stay by the fire and keep warm." Anna : "I need to get to Kristoff."
[36] Kristoff
this." "I can't accept

Anna

$:$ "You have to. No returns.
No exchanges. Queen's
orders. She's named you the
official Arandelle Ice Master
and Deliverer."

\section{Disarmer}

Disarmer is used to pre-empt the hearer's potential objection, as follows.

[37] Anna : "I'm so sorry about what happened. If I'd have known..."

Elsa : 'No, no, no. It's okay. You don't have to apologize, but you should probably go, please."

[38] Anna :"Elsa, wait."

Elsa : "I'm just trying to protect you."

Anna : "You don't have to protect me. I'm not afraid. Please don't shut me out again."

As seen in the examples above, the speakers utter something that might be uttered by the hearers to refuse the requests. By indicating their awareness of a potential offense of their requests before uttering their requests, the speakers anticipate possible refusal

\section{Imposition minimizer}

As it is also called as cost minimizer, the speaker believes that the hearer can be persuaded to carry out the request by decreasing the cost of the request.

[39] Grand Pabbie : "But don't worry, I'll leave the fun.

She will be okay."
[40] Anna "You
should probably wait out here."
Kristoff : "What?"

Anna: "Last time I introduced her to a guy, she froze everything."

Kristoff : "But, but.. Oh, come on! It's a palace made of ice. Ice is my life!"

$\begin{array}{lc}\text { Olaf } & \text { :"Bye, Sven." } \\ \text { Anna } & \text { :"You too, Olaf." } \\ \text { Olaf } & \text { :"Me?" } \\ \text { Anna : "Just give us a minute." }\end{array}$

The examples above show that all the speakers are trying to make the cost that has to be paid by the hearers when performing the requests minimized. By saying that he will leave the fun and making sure that Anna will be okay, Grand Pabbie in example [39] asks the King not to worry about it. As all requests in the examples above are fulfilled, it can be concluded that the hearers are more likely to fulfill the requests performed to them if the imposition of fulfilling the requests is minimum.

\section{Sweetener}

Putting the hearer into positive mood is also a strategy that can be done to make the request performed, known as sweetener. The examples are as follows.

[41] Oaken : "Big summer blowout. Half off swimming suits, clogs, and a sun bath of my own invention, yah?"

Anna : "Oh, great. For now, um, how about boots? Winter boots and dresses?"

[42] Anna : "He's just like the one we built as kids... Elsa, we were so close. We can be like that again." 
Elsa : "No. We can't. Goodbye, Anna."

[43] Olaf : "Hey, Anna! Sven! Where did you guys go? We totally lost Marshmallow back there. (to Marshmallow) Hey!

We were just talking about you. All good things, all good things."

[44] Anna : "Do you like it?" Kristoff : "Like it? I love it! I could

kiss you. I could. I mean, I'd like to. I'd... May I? We me. I mean, may we? Wait, what?"

Anna :"We may."

It can be seen that the entire sweetener in the examples above is uttered before the speakers utter their requests. Based on the examples above, positive mood can affect the hearers in deciding to fulfill the request or not. Meanwhile, the requests are still possible to be ignored when the hearers are in the negative mood, for example when they are feared or angry, as in example [42], Elsa is haunted by the past that she hurt her sister, and in example [43], Marshmallow is a mad-gigantic snow-monster created by Elsa to get Anna, Kristoff, and Olaf leave her palace.

\section{Promise of reward}

A reward offered to the hearer for fulfilling the request is also one of the strategies employed to persuade the hearer performing the request.

[45] Oaken : "That'll be forty." Kristoff : "Forty? No, ten."

Oaken : "Oh dear, that's no good. See, these are from our winter stock, where supply and demand have big problem."

Kristoff : "You want to talk about a supply and demand problem? I sell ice for a living."

Oaken : "Still forty. But I will throw you in a visit to Oaken's sauna."

As seen in the example above, the speaker promises to give the hearer a reward if his/her request is performed.
Although this strategy gives advantage for the hearer, the request modified with promise of reward is still possible to be ignored, as seen in the context that Kristoff decides to cancel his purchasing because he does not have enough money.

Based on the explanation above, direct request seems to be the most preferred strategy in uttering request and grounder seems to be the most preferred external modification strategy in modifying request. Furthermore, the choice of the strategies might be affected by the social variables the characters have. Mood seems to have affected the requests fulfillment, as in the movie it shows that love, fear, and even betrayal, are some factors that make them fulfill or ignore other's requests. Since all of them have their own desires, other's desires uttered through requests which are in opposite with theirs are more likely to be ignored.

In addition, the interesting things found in the data is the use of imperatives such as, 'wait', 'see', and 'look' in certain context which are considered by the writer not as requests although syntactically, they are similar. Some findings are as follows.

[46] Elsa : "Who's this?
Wait, it does not matter."
[47] Kristoff :"Wait, what?"
[48] Oaken : "See, these
are from our winter stock, where ..."
[49] Anna :Look, I know
how to stop this winter."
[50] Olaf :Wait, what am I
looking at right now?"

Those imperatives above are not considered as requests because those imperatives are words used commonly in conversation which the speakers do not ask for the actual acts of waiting, seeing, or looking to be performed. Besides, the hearers even do not have chances to decide to fulfill them or not since they also do not realize that the speakers ask them to perform the acts of waiting, seeing, or looking. Since those imperatives are used 
in conversational context, both of the speakers and the hearers more likely do not realize that they are asking for something and asked for something.

Contextually, those imperatives are different from the following.

\section{[51] Anna : Elsa, wait." [52] Anna : "Alright wait a second."}

The examples above are considered as requests because 'wait' in those examples requires a real act of waiting which can be performed. However, since the writer only focuses on investigating requests, the examples of the imperatives considered not as requests might be considered as other acts, for example, orders.

\section{CONCLUDING REMARKS}

This research on the linguistic behavior in uttering requests is one of the ways to study speech acts. This study explores the request head acts and external modifications. The results of this research show that the movie entitled Frozen which takes 92 minutes for the duration contains 76 requests, and from those requests, there are found 34 external modifications modifying the requests.

It seems that the preferred strategy in uttering requests is direct strategy, with $50(65.79 \%)$ occurrences, which might be caused by the main characters' relationships, introduced in the story to each other as siblings, friends, or even lovers. As quoted in Félix-Brasdefer (2005: 71), higher levels of directness in uttering requests are observed in situations where the relationships are close and equal. Moreover, it can be concluded that requests are divided into two types, direct and indirect requests. Direct requests are requests which convey the speakers' desires explicitly and address the hearers as the performers of the requested act directly, indicated by the appearance of pronoun 'you' in the utterances. In the contrary, indirect requests do not convey the speakers' desires explicitly and do not address the hearers as the performers of the request directly. Thus, there is a kind of requests between direct and indirect request which is recognized when the request conveys the speaker's desire explicitly but does not address the performer of the requested act directly, or vice versa, known as conventionally indirect request.

This present research also shows that the external modifications are essential to be employed in the requests in order to decrease the force of the requests. Based on the external modification strategies proposed by Blum-Kulka, House and Kasper (qtd. in Schauer, 92), grounder seems to be the most preferred strategy employed in modifying request, with 23 $(67.65 \%)$ occurrences. As seen in the results, the preference in modifying requests is affected by the easiness in employing the external modifications, as grounder can be easily employed by uttering anything related to the requests, without considering the hearers' preparation (preparator), being modest by pre-empting the hearer's potential objection (disarmer), minimizing the cost of the requests (imposition minimizer), being flattery (sweetener), and promising a reward. It should be noted that although requests are uttered with external modifications, they still have possibility to be ignored, as it is the natural characteristic of requests that the choices to perform the act or not are up to the hearers.

Compared with Félix-Brasdefer's (2005), Putro's (2009), and Fukushima's (2011) researches, the results of the present study are consistent with those previous researches which found that directness should not be considered impolite, but rather seen as a way of expressing closeness. Although this research does not discuss the variable of age, familiarity, social status and or even cultural variables of the speakers unlike in those previous researches, this research can still be used as a basic material to 
study pragmatics, especially in uttering requests. This research can also be adapted to the needs of advanced learners of all ages and in both English as a second language and English as foreign language contexts, as this research illustrates the oftentimes subtle manner in which requests can be made contextually and syntactically, the scale of directness to indirectness, and the external modifications that precede or follow requests in order to mitigate the impact. In order to investigate the requests in more detail, further research on these will be needed.

\section{BIBLIOGRAPHY}

Blum-Kulka, S. \& Olshtain, E. "Requests and Apologies: A Cross-cultural Study of Speech Act Realization Patterns (CCSARP)." Applied Linguistics 5(3), 1984: 196-213. Print.

Cutting, Joan. Pragmatics and Discourse: A Resource Book for Students. London: Routledge, 2002. Print.

Eslami, Zohrer R. \& McLeod, Kent D. "Request: It's 8 O'clock in the Morning- Are You Watching Television?" Pragmatics from Research to Practice: Teaching Speech Acts, __ : 19-28. Print

Félix-Brasdefer, J. César. "Indirectness and Politeness in Mexican Requests." Selected Proceedings of the 7th Hispanic Linguistics Symposium, ed., by David Eddington, 66-78. Somerville,

ney Studios Motion Pictures, 2013. Film.
MA: Cascadilla Proceedings Project, 2005. Print.

Fukushima, Saeko. "External Mitigation: Supportive Move in Japanese Requests." The Tsuru University Graduate School Review, 2011: 85-101. Print.

Putro, Yupiter Aryo. "Indonesian Students' Requests in English: Forms, Perspective and Modifiers." Diss. Universitas Gadjah Mada, 2009. Print.

Schauer, Gila A. Interlanguage Pragmatic Development. New York: Continuum International Publishing Group, 2009. Print.

Sofyan, Ahmad \& Rusmi. "The Realization of Request Strategies by Non-Native Speakers of English." Ragam Jurnal Pengembangan Humaniora 11(2), 2011: 69-81. Print.

Yule, George. Pragmatics. Oxford: Oxford University Press, 1996. Print.

\section{Electronic References}

"Requests: Research Notes. "The Center for Advanced Research on Language Acquisition. CARLA, 2014. Web. 22 July 2014.

Félix-Brasdefer, J. César. "Speech Acts: Requests." Discourse Pragmatic: Language and Culture Resources for Instructor, Students, and Researchers for Spanish Linguistics. Indiana University, 2007. Web. 22 Apr. 2014.

Frozen. Dir. Chris Buck \& Jennifer Lee. Walt

Dis 